\title{
Analysis of Countermeasures to Enhance the Competitiveness of Fujian Port
}

\author{
Zhong Chen \\ School of Economics and Management, Fuzhou University \\ of International Studies and Trade
}

\begin{abstract}
Port is an important carrier of export-oriented economic development. Port, as a main body of competition, is particularly required to improve the competitiveness of the port and better serve the development of foreign trade. As an export-oriented coastal province, Fujian Province has opened its sea and air ports to the outside world in recent years, which has effectively served and ensured the needs of the development of open economy and played an important role in promoting the development of foreign trade in Fujian Province. However, compared with other developed coastal areas, the handling capacity and throughput of Fujian ports are still relatively low in the coastal provinces and cities due to the small economic aggregate, small industrial scale, undeveloped comprehensive transportation system and the difficulty in hinterland expansion.
\end{abstract}

Keywords-Sea ports; Competitiveness Foreign trade development

\section{INTRODUCTION}

As an important carrier of export-oriented economic development, the promotion of port competitiveness has an important practical significance for the development of foreign trade. In recent years, Fujian's sea and air ports have been opened to the outside world in an all-round way, which promotes the better and faster development of our province's foreign trade. At present, the central government supports Fujian in accelerating its development, and the "multi-regional superposition" of the core areas of the Maritime Silk Road, the new national-level zones, and the Fujian Free Trade Zone has brought about policy, funds, and opening up elements, which have also brought about many opportunities for Fujian ports to further develop externally. However, we should also see that in today's economic globalization, Fujian ports are still facing domestic competition, and also neeed to participate international competition in the wider region, the competition between ports is particularly fierce. Therefore, it is of great significance to lay a foundation for the rapid development of export-oriented economy and foreign trade in Fujian Province by finding out the shortcomings of Fujian port, adjusting the development strategy, and promoting the expansion of the overall scale of the port and the improvement of its efficiency.

\author{
Wenying Chen \\ School of Arts and Sciences, University of Washington, \\ Seattle, USA
}

\section{Analysis of the Present Situation of Port DEVELOPMENT IN FUJIAN PROVINCE}

\section{A. General Situation of Sea Port Development in Fujian Province}

There are 7 sea ports in Fujian Province, namely Fuzhou Port, Xiamen Port, Quanzhou Port, Zhangzhou Port, Putian Port, Ningde Port and Pingtan Port, which are open to the outside world, with 24 ports and 215 berths. Sea port is mainly accessible to Hong Kong, Taiwan, the Philippines, Vietnam, Singapore, the United States, Australia and other regions, entry and exit personnel are mainly personnel for tourism, overseas Chinese, public/business-oriented personnel. Goods for import and export mainly include coal, oil, iron ore, steel, cement, wood, grain, chemical raw materials, machinery and equipment, non-ferrous metals and so on.

\section{B. Operation Situation of Fujian Sea Port Development}

In 2016, the foreign trade freight volume of Fujian ports reached $212,238,000$ tons, with $0.4 \%$ year-on-year growth, including 212.016 million tons of foreign trade freight volume of Fujian sea ports, with $0.4 \%$ year-on-year growth; The number of people entering and leaving the port was 7.423 million, with $7.4 \%$ year-on-year increase, of which 2.109 million people entered and left the sea port, with $0.1 \%$ year-on-year increase. The operation scale of Xiamen Sea Port and Fuzhou Sea Port accounts for the absolute proportion of the sea ports of Fujian Province. During the Twelfth Five-Year Plan period, the port foreign trade freight volume of our province increased by $10.9 \%$ annually on average, and the container throughput increased by $8.0 \%$ annually on average. Port integrated channel is constantly expanding, port radiation capacity in the central and western regions was further strengthened, attracting more and more goods sources exported from our province; the proportion of goods from outside the province in total exports of our province is increased from $15.5 \%$ in 2013 to $21.2 \%$ in 2015 . 
TABLE I OPERATION SCALE OF XiAMEN Port AND FuZHou PorT

\begin{tabular}{|c|c|c|c|}
\hline \multirow{2}{*}{\multicolumn{2}{|c|}{ Port operation scale }} & \multicolumn{2}{|l|}{ City } \\
\hline & & Xiamen & Fuzhou \\
\hline \multirow[b]{2}{*}{ Foreign trade freight volume of sea port } & Total quantity (10,000 tons) & 9792.7 & 4778.6 \\
\hline & $\begin{array}{l}\text { Proportion in the whole } \\
\text { province (\%) }\end{array}$ & 46.2 & 22.5 \\
\hline \multirow{2}{*}{ Marine foreign trade container of sea port } & $\begin{array}{l}\text { Total quantity } \quad(10,000 \\
\text { TEUs })\end{array}$ & 704.1 & 152.4 \\
\hline & $\begin{array}{l}\text { Proportion in the whole } \\
\text { province }\end{array}$ & 80.7 & 17.5 \\
\hline \multirow[b]{2}{*}{ Port entry and exit } & Total $(10,000$ person-times $)$ & 183.6 & 6.8 \\
\hline & $\begin{array}{l}\text { Proportion in the whole } \\
\text { province }\end{array}$ & 87.1 & 3.2 \\
\hline
\end{tabular}

Analytic Hierarchy Process (AHP) was first proposed by T.

\section{AsSESSMENT ON FuJian SEA PORT COMPETITIVENESS}

A. Port Competitiveness Assessment Based on Analytic Hierarchy Process

1) Overview of Analytic Hierarchy Process L. Saaty in the mid-1970s. It decomposes the complex problems into many parts and arranges the parts according to the objective, criterion and scheme to form a multi-level and multi-objective hierarchical decision-making model. The weighting steps of sea port competitiveness evaluation index system by AHP method are decomposed as follows:

TABLE II SPECIFIC STEPS FOR DETERMINING THE WEIGHT OF INDEX SYSTEM BY AHP

\begin{tabular}{|l|l|}
\hline Steps & Main points \\
\hline 1 & $\begin{array}{l}\text { This paper analyzes the evaluation index system of sea port competitiveness, and establishes the } \\
\text { hierarchical structure model }\end{array}$ \\
\hline 2 & Questionnaires were used to investigate experts and construct judgment matrix \\
\hline 3 & $\begin{array}{l}\text { The weights of each evaluation index of the element layer and the scheme layer are calculated, and } \\
\text { consistency check is carried out. }\end{array}$ \\
\hline 4 & The combination weights of evaluation indexes are calculated. \\
\hline
\end{tabular}

2) Establishment and Hierarchy of Evaluation Index

Based on the predecessors' research results and through the practical operation research and analysis, the following evaluation index system of sea port competitiveness is established.

\section{a) Sea Port Scale}

This index is mainly used to evaluate the production capacity of the port. The cargo throughput of port that can be completed within one year is the main index to measure the production capacity of the port, which reflects the actual cargo volume loaded and unloaded through the port. Foreign trade container throughput is to measure the degree of the port to adapt to the process of economic globalization.

\section{System}

\section{b) Port Infrastructure and Collection and Distribution}

This index is mainly used to wholely assess the natural conditions, locaiton and related hardware conditions necessary for the port competition, and the port construciton conditions are essential to the handling capacity. The industrial foundation of our province is relatively weak, and it is inevitable for economic hinterland of port enterprises to extend to the inland area. Therefore, the convenience degree of collection and distribution system plays a crucial role in the radiation capacity of port.

\section{c) Economic Situation of Port Cities}

The development of the sea port production is supported by the secondary industry of the port city. The port city is lagging behind and the development of the port will become no-source water. Whether the economic hinterland is developed or not and its development degree, even its industrial structure have a tremendous impact on the port development.

\section{d) Soft Environment of Port}

Sea port charges are one of the measurement indexes for enterprises to choose ports for import and export. In order to realize high-efficient and convenient operation of port, besides the advanced equipment and perfect management, it needs to be seamlessly connected with the port inspection departments. Information technology has become an essential competitive element of modern sea port. 
3) Relevant Sea Port Competitiveness Index

Through Delphi method, the paper evaluates and compares the scores of 10 indicators related to sea port competitiveness, and gives the scores for the quantitative and qualitative indicators by consulting experts and refering to the data. Among them, through the relevant port research, understanding, as well as the collation of data from National Port Office and the official website, the relevant indexes are obtained, and the data used is subject to 2015 version. Seven indicators are scored by experts at maritime sector and ports and persons in charge of import and export enterprises.

TABLE III SEA Port COMPetitiveness EVALUation INDEX

\begin{tabular}{|l|l|l|l|}
\hline \multirow{2}{*}{ Level I index } & Level II index & $\begin{array}{l}\text { Index } \\
\text { Type }\end{array}$ & Data source \\
\hline \multirow{3}{*}{ Sea port scale } & Import and export freight volume & Quantitative & Data Statistics \\
\cline { 2 - 4 } & $\begin{array}{l}\text { Number of inbound and outbound } \\
\text { visitors }\end{array}$ & Quantitative & Data Statistics \\
\hline \multirow{3}{*}{$\begin{array}{l}\text { Port infrastructure and } \\
\text { Collection and distribution system }\end{array}$} & Conditions for Port Construction & Qualitative & Score by experts \\
\cline { 2 - 4 } & Port infrastructure & Qualitative & Score by experts \\
\cline { 2 - 4 } & $\begin{array}{l}\text { Convenience degree of collection and } \\
\text { distribution system }\end{array}$ & Qualitative & Score by experts \\
\hline \multirow{3}{*}{ Economic situation of port cities } & $\begin{array}{l}\text { Economic development degree of } \\
\text { hinterland }\end{array}$ & Qualitative & Score by experts \\
\cline { 2 - 4 } & Hinterland industrial structure & Qualitative & Score by experts \\
\hline \multirow{3}{*}{ Soft environment of port } & Import and export charges & Qualitative & Score by experts \\
\cline { 2 - 4 } & Customs clearance efficiency & Qualitative & Score by experts \\
\cline { 2 - 4 } & Information service level of port & Qualitative & Score by experts \\
\hline
\end{tabular}

Among them, the quantitative indexes are converted according to the ranking of each port in 80 ports across the country, and then the corresponding scores are obtained. different scoring levels of excellent (8-10 points), good (6-8 points), general (4-6 points), poor (0-4 points).

Qualitative indexes are averaged after expert scoring, based on

TABLE IV DATA OF GRADING INDEX OF SEA PORTS

\begin{tabular}{|c|c|c|c|c|c|c|}
\hline $\begin{array}{l}\text { Level I } \\
\text { Index }\end{array}$ & Level II index & $\begin{array}{l}\text { Xiamen } \\
\text { Port }\end{array}$ & $\begin{array}{l}\text { Fuzhou } \\
\text { Port }\end{array}$ & $\begin{array}{l}\text { Shanghai } \\
\text { Port }\end{array}$ & $\begin{array}{l}\text { Qingdao } \\
\text { Port }\end{array}$ & Dalian Port \\
\hline \multirow{2}{*}{ Sea Port Scale } & $\begin{array}{l}\text { Import and export freight } \\
\text { volume }\end{array}$ & 8.2 & 7.5 & 10 & 9.7 & 8.7 \\
\hline & $\begin{array}{l}\text { Number of inbound and } \\
\text { outbound visitors }\end{array}$ & 9.5 & 6.8 & 9.8 & 8.7 & 8.2 \\
\hline \multirow{3}{*}{$\begin{array}{l}\text { Port } \\
\text { infrastructure } \\
\text { and collection } \\
\text { and } \\
\text { distribution } \\
\text { system }\end{array}$} & $\begin{array}{lll}\begin{array}{l}\text { Conditions } \\
\text { Construction }\end{array} & \text { for } & \text { Port } \\
\end{array}$ & 8.3 & 8.6 & 9.5 & 9.1 & 8.8 \\
\hline & Port infrastructure & 8.3 & 7.8 & 9.3 & 8.9 & 8.4 \\
\hline & $\begin{array}{l}\text { Convenience degree of } \\
\text { collection and distribution } \\
\text { system }\end{array}$ & 8.1 & 7.5 & 9.5 & 8.8 & 8.2 \\
\hline \multirow{2}{*}{$\begin{array}{l}\text { Economic } \\
\text { Situation of } \\
\text { Port Cities }\end{array}$} & $\begin{array}{l}\text { Economic development } \\
\text { degree of hinterland }\end{array}$ & 6.2 & 7.3 & 9.6 & 8.6 & 8.1 \\
\hline & $\begin{array}{l}\text { Hinterland industrial } \\
\text { structure }\end{array}$ & 7.2 & 6.5 & 9.1 & 8.2 & 7.4 \\
\hline \multirow{3}{*}{$\begin{array}{l}\text { Ports: } \\
\text { Soft } \\
\text { environment }\end{array}$} & Import and export charges & 8.9 & 9.2 & 7.9 & 8.5 & 8.3 \\
\hline & Customs clearance efficiency & 9.1 & 8.7 & 9.3 & 9.1 & 8.9 \\
\hline & $\begin{array}{l}\text { Information service level of } \\
\text { port }\end{array}$ & 8.9 & 8.1 & 9.5 & 9.2 & 9.1 \\
\hline
\end{tabular}

According to the above data, the corresponding data will be multiplied by the weight coefficient of the corresponding index for amending, so we can get the comprehensive competitiveness evaluation index of each port. The individual 
$P=\sum_{i=1}^{n} c_{i} w_{i}$

evaluation result is expressed by $\boldsymbol{C}_{i}$, the weight of the index

layer relative to the overall objective is expressed by $w_{i}$, and the comprehensive evaluation index is expressed by $\mathrm{P}$

TABLE V Table 6 Statistics of Comprehensive Evaluation Index of Sea Ports

\begin{tabular}{|l|l|l|l|l|l|}
\hline Sea port & $\begin{array}{l}\text { Xiamen Port } \\
\text { Port }\end{array}$ & $\begin{array}{l}\text { Fuzhou Port } \\
\text { Port }\end{array}$ & $\begin{array}{l}\text { Shanghai Port } \\
\text { Port }\end{array}$ & $\begin{array}{l}\text { Qingdao Port } \\
\text { Port }\end{array}$ & $\begin{array}{l}\text { Dalian Port } \\
\text { Port }\end{array}$ \\
\hline P & 7.85 & 7.49 & 9.74 & 9.17 & 8.46 \\
\hline
\end{tabular}

\section{B. Comparison of the Evaluation Results}

Based on AHP model, it can be seen that although the soft environment of Fujian sea port is basically the same as that of Shanghai sea port, Qingdao sea port and Dalian sea port, there is still a big gap between Fujian sea port and these hub-type sea port like Shanghai sea port, Qingdao sea port and Dalian sea port in terms of port scale, port infrastructure and collection and distribution system, and the economic situation of the port city etc..
(1)The number of sea ports in our province is large but the volume is small. In 2015, Xiamen Port ranked first in the province in terms of foreign trade cargo and maritime trade container throughput, but compared with other major coastal ports, it lagged behind Shanghai Port, Ningbo Port and Dalian Port. Statistically speaking, there is a big gap between the throughput of Fujian sea ports and the throughput of domestic advanced sea ports, and the total freight volume of the port is not big.

TABLE VI STATISTICS OF FUJIAN PORT OPERATION IN 2016

\begin{tabular}{|l|l|l|l|l|l|l|}
\hline Port & $\begin{array}{l}\text { Foreign trade } \\
\text { freight volume } \\
(10,000 t)\end{array}$ & $\begin{array}{l}2016 \\
\text { Ranking } \\
\text { (rank) }\end{array}$ & $\begin{array}{l}\text { Foreign trade } \\
\text { container volume } \\
(10,000 \text { TEUs })\end{array}$ & $\begin{array}{l}2016 \\
\text { Ranking }\end{array}$ & $\begin{array}{l}\text { Entry and Exit } \\
\text { Staff quantity } \\
(10,000 \\
\text { person-times })\end{array}$ & $\begin{array}{l}2016 \\
\text { Ranking }\end{array}$ \\
\hline $\begin{array}{l}\text { Fuzhou Port } \\
\text { Port }\end{array}$ & 4778.6 & 20 & 152.4 & 12 & 6.8 & 25 \\
\hline $\begin{array}{l}\text { Xiamen Port } \\
\text { Port }\end{array}$ & 9792.7 & 14 & 704.1 & 5 & 183.6 & 4 \\
\hline $\begin{array}{l}\text { Quanzhou } \\
\text { Port } \\
\text { Port }\end{array}$ & 3611.2 & 19 & 11.3 & 21 & 11.9 & 19 \\
\hline $\begin{array}{l}\text { Zhangzhou } \\
\text { Port } \\
\text { Port }\end{array}$ & 859.3 & 31 & 1.3 & 25 & -- & -- \\
\hline $\begin{array}{l}\text { Putian Port } \\
\text { Port }\end{array}$ & 1024.1 & 38 & 1.5 & 43 & -- & - \\
\hline $\begin{array}{l}\text { Ningde Port } \\
\text { Port }\end{array}$ & 1128.7 & 35 & -- & - & - & - \\
\hline $\begin{array}{l}\text { Pingtan Port } \\
\text { Port }\end{array}$ & 6.9 & -- & 1.6 & -- & 8.7 & - \\
\hline
\end{tabular}

(2)This economic volume is not big in our province, the industry foundation is relatively weak, and the strength of port industry to support the port development is not strong.

Firstly, the industrial foundation of our province is relatively weak. In 2016, the total GDP of our province was RMB 2851.915 billion, with the increase of $8.4 \%$, accounting for only $3.8 \%$ of the national total. Secondly, the port industry in our province is not fully developed, the scale is small, and the cluster effect is not prominent. Thirdly, interactive linkage between the port and the city, and the industries is not close enough.

(3) Port is scattered, with small-scale, high operating costs, low efficiency. Port wharves in our province are scattered, for part of the ports, construction of supporting facilities including collection and distribution system, navigation channels, tugboats, port inspection facilities is relatively backward. For most of the ports in our province, there are no large-scale port enterprises with strength to lead the construction and operation. The contradiction between low-level repeated construction of ports and vicious competition is prominent. The problems of the same type of ports in our province, such as inadequate division of labor and cooperation and differential development, low-level expansion and distribution, homogeneous development of functional positioning, are more prominent.

(4) Collection and distribution system is not perfect, railway transport capacity is insufficient, logistics costs are too high, ad the port radiation capacity in the central and western regions is weak. Railway transportation is greatly limited, and 
the overall capacity of the highway network is insufficient. The construction of drainage channel is relatively backward, so it is difficult for the port to expand the cargo source in the hinterland.

(5) The soft environment at the sea port continues to be improved but the effect is not prominent. The efficiency of customs clearance in our province has been greatly improved and the customs clearance environment has been continuously optimized. Comparatively speaking, the customs clearance policy adopted by the advanced ports in the surrounding provinces and cities is more flexible. Although the total cost of foreign trade cargo owners is slightly lower than that of neighboring provinces, there is still a gap in port service level and information management level between our port and other advanced ports such as Shanghai Port.

(6) There are fewer international routes, and there is a serious outflow of local cargo. In our province, port foreign trade container route is few. At present, there are 128 foreign trade container routes, and 607 flights per month in our province. Among them, there are 89 routes and 390 flights in Xiamen Port, respectively corresponding to $48.9 \%$ and $48.1 \%$ of those in Ningbo Port. Fuzhou Port has 27 routes and 142 flights, respectively corresponding to $14.8 \%$ and $17.5 \%$ of those in Ningbo Port. There are fewer routes for liner shipping, flights are not congested, and many non-direct shipping and other issues directly prevent the foreign trade cargo owners from choosing our port for entry and exit.

\section{Policy Suggestions on IMPROVIng the COMPETITIVENESS OF OUR PORTS AND SERVING THE DEVELOPMENT OF FOREIGN TRADE}

\section{A. Optimize the layout of port-related industries and promote the agglomeration of port-surrounding industries.}

Construct port-surrounding industrial chain and foster a batch of port- surrounding industrial leaders with high relevance, prominent main business, strong innovation ability and strong driving ability. Strengthen the port-surrounding industrial planning of the province, and clearly position the port-surrounding industrial parks. Vigorously build important industrial bases close to the port and actively support the integration, adjustment, and structural optimization and upgrading of existing port-surrounding industries. Build a commodity trading platform close to the port, build a commodity circulation system that integrates domestic and foreign trade, and promote the construction of China-ASEAN Seafood Exchange and Commodities Trading Center. With the development of the Belt and Road Initiative, speed up port opening and strengthen exchanges and cooperation with Belt and Road countries in port and terminal construction management and route expansion.

\section{B. Define the functional positioning of ports and promote differentiated and specialized development.}

Intensify the shift from building all-round ports to cultivating specialized ports, avoid internal homogenization and vicious competition, and promote the dislocated and intensive development of sea ports Broaden the channels of attracting investment and actively strive for the approval of major projects at the national level in order to inject development momentum into Fujian's economic and social development and port leapfrog development, around the construction of core area of Maritime Silk Road, the free trade experimental zone and the intelligent ocean. Gave full play to the role of designated ports in Fuzhou, Xiamen and ports with the basic guarantee capacity for inspection and quarantine of imported chilled aquatic products, and strengthen the development of specialized ports.

\section{Accelerate the construction of the collection and distribution system and expand the radiation corridor in the central and western regions.}

Strengthen the planning and construction of the collection and distribution system to achieve the close connection of various modes of transportation. Promote the integrated logistics development of "port-navigation-land" , actively develop sea-rail combined transportation, land-sea combined transportation, water-water transfer, trailer pick-up transportation and container intermodal transport, and promote the integrated transport mode of "door-to-door" and "one ticket ", so as to facilitate smooth connection and efficient transfer of various modes of transportation. Accelerate the construction of trunk and branch of freight railways in the region, intensify coordination, focus on improving freight capacity of trunk, and coordinate to reduce railway rates. Improve port collection and distribution corridors, and build and upgrade key trunk highways. Speed up the construction of a fast and convenient highway network, improve the highway collection and distribution system, and comprehensively improve the port's operational efficiency and service level.

\section{Further improve the comprehensive port service system and enhance the competitiveness of the port.}

Encourage private capital and foreign capital to cooperate with port operation enterprises and international container transportation and generation enterprises in our province and actively promote the cooperation in investment of port and shipping. Make efforts to promote Fujian ports and vigorously expand container shipping routes for foreign trade. Rationally distribute container sea-rail combined transportation network in inland areas, jointly develop land ports with local authorities, extend special freight lines to land ports, develop new corridors accessible to sea in central and western regions, and expand the radiation and leading role of ports. Integrate port shoreline resources, overall control and efficiently use the port, shoreline and other marine resources in the province, improve port supporting service system. Strengthen the linkage development of port and port-surrounding logistics park, and expand modern logistics services. Strengthen the construction of transportation facilities around the port platform and explore value-added services such as changing, subcontracting and dismantling. Accelerate the healthy development of the port intermediary 
service industry and create a standardized, transparent and orderly market environment.

\section{E. Give full play to self advantages and expand the scale of goods import and export}

Implement the policy of discounting interest on imports, promote the import of advanced technology and equipment, key spare parts and resource-intensive products, and expand the import of important resources. Take advantage of window phase in which the price of international commodities is low and the country opens to the crude oil import processing re-export. Encourage enterprises to "go out" and build a batch of key commodity import bases with strong radiation capacity. Expand the pilot scope of comprehensive foreign trade service enterprises, encourage Yidatong to continue to expand its export scale, guide local traditional foreign trade circulation enterprises with conditions to transform into comprehensive foreign trade service enterprises, vigorously cultivate new foreign trade formats, and promote new formats such as financial leasing, cold chain logistics, bonded display, and aircraft maintenance to move closer to the pilot free trade zone, so as to promote the growth of trade across the province through demonstration of the pilot free trade zone.

Deepen the cross-strait cooperation mechanism and promote the normal operation of Fujian-Taiwan motor vehicle interchange.

\section{F. Further improve the customs clearance environment and enhance the efficiency of customs clearance}

Deepen the reform of "three mutual" on customs clearance, strengthen the intensive construction of infrastructure, and promote the sharing of inspection sites and equipment at ports. Promote the reform of integrated customs clearance operations, and carry out comprehensive law enforcement on a pilot basis, which includes "joint inspection at the front desk and separate disposal at the back office"; Strengthen classified management, broaden the scope of centralized application and advance application by enterprises, and increase the proportion of non-intrusive and non-interfering inspections. Promote trans-regional port cooperation, implement policy of independently choosing customs clearance ports by the applicants, realize one-time declaration based on multimodal transport and one-time inspection at the designated place of transport (place of departure); Promote mutual recognition and communication among inspection and quarantine departments within the province; Optimize the supervision mode of customs clearance at land ports and promote the customs clearance integration of land ports and ports. Further expand and improve the construction of a "single window" for international trade, optimize the procedures for customs declaration and inspection and joint inspection of ships, expand cross-border payments, supervision intellectualization and customs clearance automatization and other whole-process electronic services; Further promote interconnection and intercommunication with neighboring provinces and cities in terms of international trade "single window" Continue to carry out the pilot work of waiving the cost of hoisting, transferring and storing goods for foreign trade enterprises that have found with no problems in inspection. Strengthen the implementation of policy of waiving the cost of hoisting, transferring and storing goods for foreign trade enterprises that have found with no problems in inspection, so as to practically lighten the burden on enterprise.

Port is an important support for Fujian Province to accelerate the development of a higher-level open economy and to build a pioneering area for participating in global competition and cooperation. By analyzing the current situation of port development in Fujian Province, this paper analyzes the opportunities and advantages of port development in Fujian Province. On this basis, this paper evaluates the competitiveness of our province's ports by AHP, and puts forward some policies and measures such as optimizing the industrial layout, speeding up the construction of collection and distribution system, perfecting the port comprehensive service system, and improving the customs clearance environment, so as to comprehensively enhance the comprehensive competitiveness of our province's ports, promote the development of our province's foreign trade, and enhance the export-oriented economic development level of our province.

\section{REFERENCES}

[1] Liping GUO. Discussion on the Core Capacity Building of Ningbo Port [J]. Chinese Journal of Frontier Health and Quarantine, 2011, 34 (06): 484-487.

[2] Zhiping LV, Zhengliang LI, Licheng ZHOU. Research on the Core Elements of Port Core Capacity Building [J]. Chinese Journal of Frontier Health and Quarantine, 2011, 34 (04): 266-268.

[3] Shuling GUAN. Research on the Enhancement of Fujian Port Competitiveness [D]. Xi'an: Chang'an University, 2012.

[4] Tianjin Sea Port Vigorously Optimizes Port Services and Constantly Improves the Level of Trade Facilitation [J]. Tianjin National People's Congress 2014 (03): 49

[5] Xingxiang ZHANG. Research on the Development Strategies of Fujian' Three Major Ports from the Perspective of "New Maritime Silk Road" [J]. Journal of Xiamen SEZ Party School, 2015, (5): 31-38

[6] Yazhen CHEN, Licheng ZHOU, Yingxue ZHOU, Ruochuan SHEN. Status Quo Analysis of Core Capacity Building of Different Types of Port [J]. Chinese Journal of Frontier Health and Quarantine, 2017, 40 (02): $133-135$

[7] Weixiang XU, Yanqing XU. Evaluation of Port Comprehensive Strength and Spatial Evolution of Main Port Hinterland in China [J] Economic Geography, 2018, 38, (5)

[8] Yuyun XU, Yuzhu HAO. Research on Export-oriented Economic Synergy and Upgrading Path between Beijing-Tianjin-Hebei Sea Port and Hinterland [J]. Business Economics Research, 2018 (07): 144-148. 